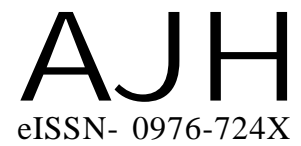

Received : 07.03.2017

Revised : 09.05.2017

Accepted : 22.05.2017

Members of the Research Forum

Associated Authors:

${ }^{1}$ Department of Fruit and Vegetable

Technology, Defence Food Research

Laboratory, MYSORE (KARNATAKA)

INDIA

${ }^{2}$ Botanic Garden of Indian Republic, Ministry of Environment and Forest, NOIDA (U.P.) INDIA

Author for correspondence : D. RAMESH BABU

S.R.Engineering College, Hasanparthy, WARANGAL (TELANGANA) INDIA

Email : rameshdamarla@ rediffmail. com
THEASIAN JOURNALOF HORTICULTURE

Volume 12 | Issue 1 | June, 2017 | 127-13

Visit us -www.researchjournal.co.in
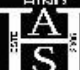

RESEARCH PAPER

DOI : 10.15740/HAS/TAJH/12.1/127-131

\title{
Rheological characteristics of muskmelon (cantaloupe) pulp
}

\section{RAMESH BABU, D.K. DAS GUPTA ${ }^{1}$ AND SANDEEP KUMAR CHAUHAN ${ }^{2}$}

ABSTRACT : The rheological characteristics of musk melon (cantaloupe) pulp was evaluated with a view to determine its flow behaviour, yield stress and applicability of common rheological models. The experimental data on rheological behaviour were analyzed on the basis of four models viz., Ostwald, Casson, Bingham and Herschel-Bulkley (H-B). However, Herschel-Bulkley model showed best fit. Consistency index $(\mathrm{K})$ was found to decrease with increase in temperature. The yield stress value determined by three methods showed in the range of 3.6 to 4.1 Pa. Yield stress calculated from stress-strain plot showed the maximum value. Overall the rheological behaviour of musk melon pulp followed the pseudo plastic with yield stress.

KEY WORDS : Fruit pulp, Rheology, Muskmelon, Flow behaviour, Modelling

HOW TO CITE THIS ARTICLE : Babu D. Ramesh, Gupta D.K. Das and Chauhan, Sandeep Kumar (2017). Rheological characteristics of muskmelon (cantaloupe) pulp. Asian J. Hort., 12(1) : 127-131, DOI : 10.15740/HAS/TAJH/12.1/127-131. 